TECHNICAL NOTE

\title{
Nondestructive DNA extraction from sperm whale teeth and scrimshaw
}

\author{
F. B. PICHLER, M. L. DALEBOUT and C. S. BAKER \\ School of Biological Sciences, University of Auckland, Private Bag 92019, Auckland, New Zealand
}

\begin{abstract}
Sperm whales (Physeter macrocephalus), have been hunted throughout their global distribution. As a result, sizeable collections of sperm whale teeth and scrimshaw are held in museum and private collections. Access to these specimens for genetic analysis is limited due to the tendency of DNA extraction techniques to destructively sample such specimens. Here we demonstrate that small amounts of bone powder, collected by drilling inside the root cavity, can yield sufficient DNA for sequencing without adversely affecting the specimen's appearance. We anticipate that owners and curators of sperm whale teeth will be more amenable to genetic analysis using this extraction method.
\end{abstract}

Keywords: DNA extraction, mtDNA, museum specimens, scrimshaw, sperm whale, teeth

Received 14 November 2000; revision accepted 3 January 2001

Sperm whales are one of the most widely distributed marine mammals, found in all the world's oceans from the equator to the edge of the polar ice (Rice 1989). Beginning in the 18th century, sperm whales in tropical and subtropical waters were extensively exploited for spermaceti oil, meat and bone. Although pelagic sperm whaling had declined by the 1900s, a resurgence after World War II again saw large numbers caught both in tropical and polar regions until the international moratorium on whaling went into effect in 1986 (Evans 1987; Dufault et al. 1999). World population numbers today probably do not exceed 1.9 million compared to pre-exploitation numbers of approximately 2.4 million (Evans 1987).

Recent genetic analyses suggest that present-day sperm whale populations have very low mitochondrial DNA (mtDNA) diversity, and show little geographical differentiation over their global range (Lyrholm \& Gyllensten 1998). It has been suggested (Whitehead 1998) that the low mtDNA diversity observed in sperm whales has resulted from 'hitch-hiking' along with the selection of matrilineally transmitted cultural traits. Whitehead (1998) also mentions that the loss of entire matrilineal family groups (i.e. entire pods) could result in significant loss of mtDNA diversity. Because sperm whales are thought to form longterm stable groups of matrilineally related individuals

Correspondence: Franz B. Pichler. Fax: + 64 (9) 373 7417; E-mail: f.pichler@auckland.ac.nz
(Whitehead et al. 1991), modern whaling could have potentially depleted genetic diversity through loss of maternal lineages.

Sperm whaling was a dangerous occupation, as depicted in paintings, woodcuts, and engravings of the era. For both commercial whalers and the indigenous people who used stranded animals as a resource, sperm whale teeth were considered valuable trophies or status symbols. Among sailors, the intricate engraving of sperm whale teeth and other ivory developed into a distinctive art form known as scrimshaw. Today, large quantities of scrimshaw and carved indigenous artefacts are found in museums and private collections throughout the world. These collections represent an almost unprecedented historical population sample for a marine species. Access to museum collections of sperm whale artefacts may allow assessment of the impact of whaling by enabling examination of genetic diversity in historic (whaling-era) sperm whale populations. However, as these specimens are valuable, usual methods of DNA extraction from tooth and bone, which require relatively large amounts of material or result in the destruction of the specimen (Merriwether et al. 1994; Pichler \& Baker 2000), will have limited use. Here we demonstrate the application of the silica-based extraction method to small quantities of bone, leaving the morphological and artistic integrity of the specimen intact.

A total of 11 sperm whale teeth, including one scrimshaw piece, were obtained from the Auckland War Memorial 


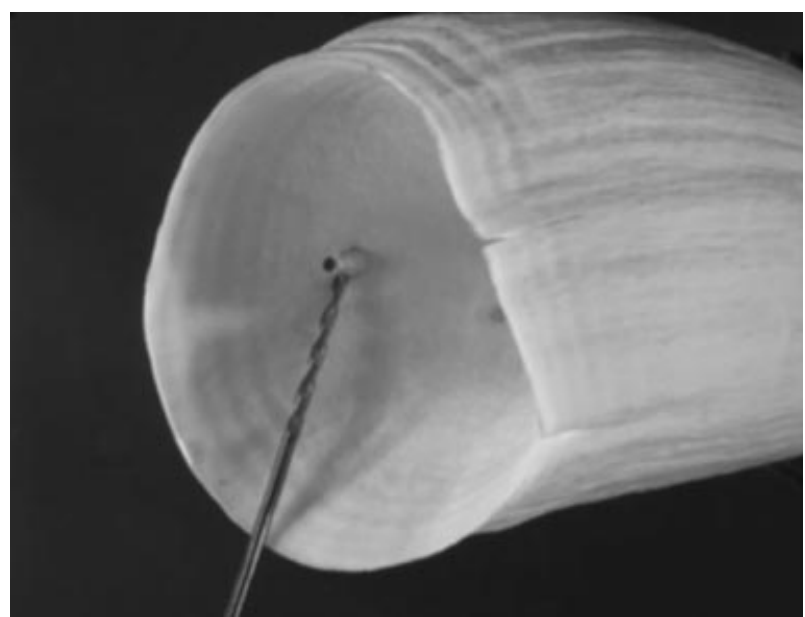

Fig. 1 The root of a sperm whale tooth (Pma 18) showing the relative size of the drill bit $(1.5 \mathrm{~mm}$ diameter $)$ and the hole produced in order to obtain sufficient tooth powder for DNA extraction.

Museum (AK), the Museum of New Zealand Te Papa Tongarewa (NMNZ), the New Zealand Department of Conservation (DOC), and the University of Auckland McGregor Museum (Table 1). Collection dates range from 1873 to 1997 . The majority of specimens were obtained from strandings or animals taken in historic whaling operations in the New Zealand-South Pacific region.

All reagents for DNA extraction were prepared in a designated 'ancient DNA' laboratory, in which no genetic work on cetacean material had been conducted. Separate areas dedicated to different phases of the extraction procedure, including polymerase chain reaction (PCR) preparation, were set up. All working surfaces were decontaminated with a wash sequence of sodium hypochlorite $(10 \%)$, hydrochloric acid $(0.1 \%)$, and ethanol (70\%). All equipment was sterilized by autoclaving and decontaminated by exposure to ultraviolet light and bleaching. All consumables used, including PCR reagents and oligonucleotide primers, were purchased especially for the project.

A cordless, variable-speed, hand-held electric drill with a $1.0-1.5 \mathrm{~mm}$ drill bit, was used to obtain $0.01-0.02 \mathrm{~g}$ of dentine-cementum powder from each tooth. A drilling speed of less than 100 revolutions per minute (r.p.m.) was used to minimize heat production, which could result in DNA degradation. The holes drilled were approximately 1.5-2.0 mm wide and 2.0-3.0 $\mathrm{mm}$ deep (Fig. 1). One to two drill holes usually provided sufficient dentine-cementum powder for DNA extraction. Holes were drilled inside or, at the base of, the root cavity to minimise visible damage to the specimen. Prior to drilling, the drill site was cleaned with 70-100\% ethanol to remove dust and particulate matter. A new, autoclaved drill bit and autoclaved collection tray made from aluminium foil were used for each specimen. Teeth were held at an incline during drilling to ensure the tooth powder produced fell into the collection tray.
Tooth powder was transferred from the tray to a sterile $2 \mathrm{~mL}$ tube by careful decanting. After the drilling of each specimen was complete, drill bits and all disposable equipment, including gloves, were discarded, and working surfaces decontaminated, as described above. Where requested, drill holes were cosmetically filled with a commercially available polymer filler and painted to retain the aesthetic appearance of the specimen.

DNA was extracted from the tooth powder using the silica-based method of Boom et al. (1990) as modified by Matisoo-Smith et al. (1997). PCR products were purified using HighPure (Boehringer Mannheim-Roche) microfiltration columns, sequenced using an ABI Prism Big Dye Terminator Cycle Sequencing Ready Reaction Kit (v.2.0, Perkin, Elmer, Inc.), and electrophoresed on an ABI377 Automated DNA Prism ${ }^{\mathrm{TM}}$ Sequencer (Applied Biosystems, Inc.).

Mitochondrial DNA control region (D-loop) fragments ranging from 550 to $800 \mathrm{bp}$ in length were successfully amplified by PCR from 10 of the 11 specimens. The tooth for which PCR amplification was not successful (Pma19) was subsequently found to be a plaster replica. Three specimens allowed amplification of the larger $800 \mathrm{bp}$ fragment, using primers, light strand DlpWH 1.5 (5'-TCACCCAAAGCTGRARTTCTA-3') and heavy strand Dlp8G (5'-GGAGTACTATGTCCTGAACA-3'). The smaller $550 \mathrm{bp}$ fragment was amplified from the remaining seven samples using an indented heavy strand primer, Dlp5 (5'-CCATCGWGATGTCTTATTTAAGRGGAA-3'). The resulting sequences were aligned by eye to a published sperm whale sequence (Accession number X72203; Arnason et al. 1993) to confirm identity. Variable sites among sequences derived from the teeth were compared to the reference sequence (Table 1). The 10 sequences represented at least four unique haplotypes, all of which matched haplotypes published previously by Lyrholm \& Gyllensten (1998), defined from the first 5' L 330 bp of the mtDNA control region. One sample, Pma20, had a haplotype (type 2) not previously seen in the Southern Hemisphere. There is no record of the tooth's origin, and based on the haplotype we suggest that the tooth most likely came from central North Pacific (frequency 0.45, Lyrholm \& Gyllensten 1998). Due to the low yield of some PCR reactions, the quality of some of the electropherograms declined along the sequence length resulting in difficulty in defining all variable sites (Table 1).

Although many historical specimens of interest are likely to yield only short mitochondrial fragments (Höss \& Pääbo 1993), nuclear fragments may be obtained from some material, dependent on specimen age and conditions of preservation (Greenwood et al. 1999). To assess whether nuclear DNA was present in the tooth extractions, PCR amplification of two microsatellite loci (EV1, $123 \mathrm{bp}$ and EV104, 158-160 bp; Valsecchi \& Amos 1996) was also attempted. These loci were amplified successfully from six of the 10 teeth. 
TECHNICAL NOTE 3

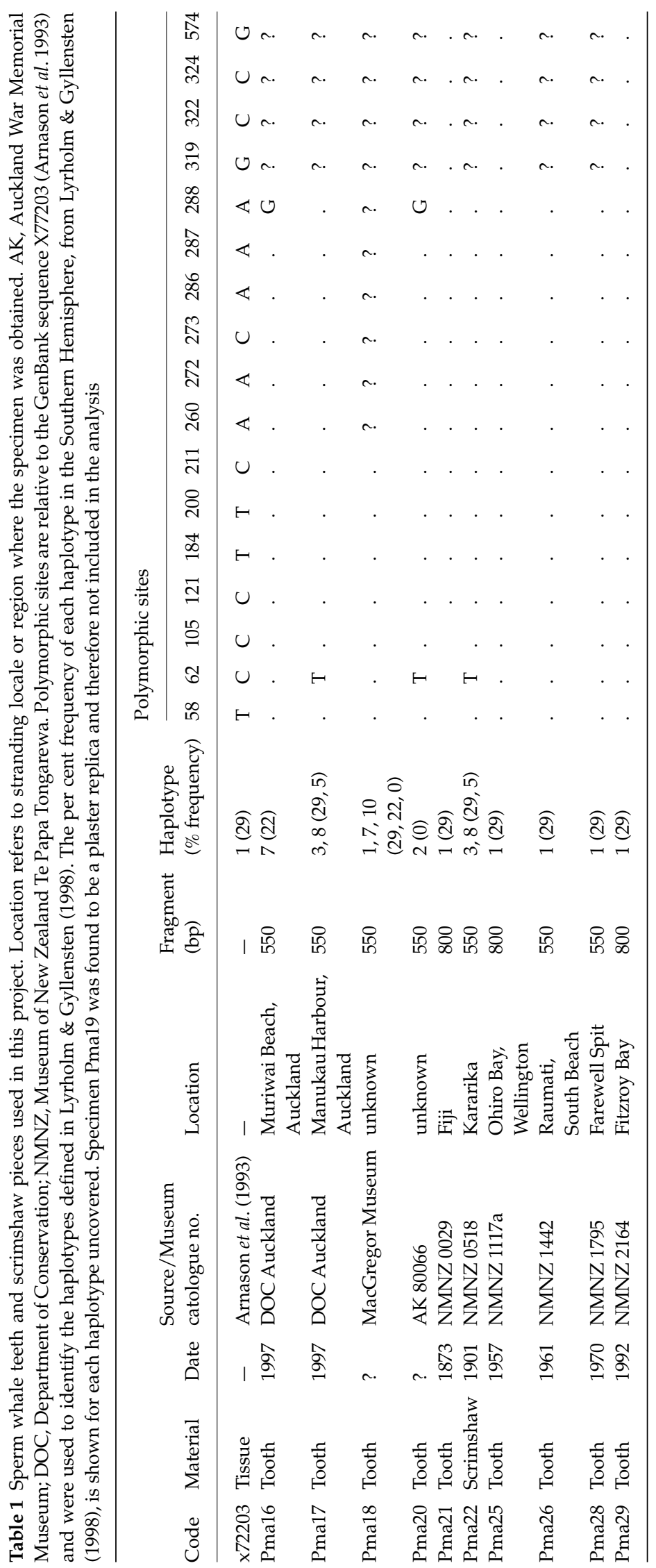




\section{TECHNICAL NOTE}

Our results demonstrate that sufficient DNA for PCR amplification and sequencing of mitochondrial loci can be obtained from sperm whale teeth and scrimshaw, using the minimally invasive drilling technique described. mtDNA fragments up to $800 \mathrm{bp}$ (maximum attempted) were amplified, suggesting that the dense mineral structure of teeth protects the nucleic acids from degradation. Historic or ancient DNA specimens rarely allow amplification of fragments over $300 \mathrm{bp}$ of nuclear or mtDNA (Höss \& Pääbo 1993). Preliminary results suggest that some specimens will also allow amplification of nuclear microsatellite loci, enabling individual identification of teeth, and thus the source animal. However, care will need to be taken for allelic dropout (Taberlet \& Luikart 1999).

As demonstrated here, silica-based extraction of low volumes of bone powder, obtained without significant damage to the specimen, can provide sufficient DNA for genetic analysis. Thus, valuable sperm whale artefacts in museum and private collections will become amenable to molecular genetic analysis. These techniques have also been successfully used to obtain DNA from beaked whale teeth and bone (MLD, unpublished data) but from smaller cetaceans it may be necessary to crush teeth (Pichler \& Baker 2000). As with the amplification of DNA from baleen plates of mystecete whales (Rosenbaum et al. 1997), the teeth of sperm whales and other odontocetes can provide a window into the genetic history of these populations.

\section{Acknowledgements}

We thank E. Matisoo-Smith for use of her ancient DNA laboratory at the University of Auckland for reagent preparation. For specimens we thank A. van Helden (Museum of New Zealand), C. Roberts (DOC), D. Cowley (Auckland University McGregor Museum), and the Auckland War Memorial Museum. This work was funded by a Marsden Fund grant to CSB.

\section{References}

Arnason U, Gulberg A \& Widegren B (1993) Cetacean mitochondrial DNA control region: sequences of all extant baleen whales and two sperm whale species. Molecular Biology and Evolution, 10, 960-970.
Boom R, Sol CJA, Jansen CL, Wertheim-van Dillen PME \& van der Noorda J (1990) Rapid and simple method for purification of nucleic acids. Journal of Clinical Microbiology, 28, 495-503.

Dufault S, Whitehead H \& Dillon M (1999) An examination of the current knowledge on the stock structure of sperm whales (Physeter macrocephalus) worldwide. Journal of Cetacean Research and Management, 1, 1-10.

Evans P (1987) Natural history of whales and dolphins. Facts on File, New York.

Greenwood AD, Capelli C, Possnert G \& Pääbo S (1999) Nuclear DNA sequences from Late Pleistocene megafauna. Molecular Biology and Evolution, 16, 1466-1473.

Höss M \& Pääbo S (1993) DNA purification from Pleistocene bones by a silica-based purification method. Nucleic Acids Research, 21, 3913-3914.

Lyrholm T \& Gyllensten U (1998) Global matrilineal population structure in sperm whales as indicated by mitochondrial DNA sequences. Proceedings of the Royal Society of London, Series B, 265, $1679-1684$.

Matisoo-Smith E, Allen JS, Lagefoged TN, Roberts RM \& Lambert DM (1997) Ancient DNA from Polynesian rats: extraction, amplification and sequence from single small bones. Electrophoresis, 18, 1534-1537.

Merriwether DA, Rothhammer F \& Ferrell RE (1994) Genetic variation in the New World: ancient teeth, bone, and tissue as sources of DNA. Experimentia, 50, 592-601.

Pichler FB \& Baker CS (2000) Loss of genetic diversity in the endemic Hector's dolphin due to fisheries-related mortality. Proceedings of the Royal Society of London, Series B, 267, 97-102.

Rice DW (1989) Sperm whale - Physeter macrocephalus Linnaeus, 1758. In: Handbook of Marine Mammals. River Dolphins and the Larger Toothed Whales, Vol. 4. (eds. Ridgeway SH, Harrison R), pp. 177-234. Academic Press, London.

Rosenbaum HC, Egan MG, Clapham PJ, Brownell RL Jr \& DeSalle R (1997) An effective method for isolating DNA from historic specimens of baleen. Molecular Ecology, 6, 677-681.

Taberlet P \& Luikart G (1999) Non-invasive genetic sampling and individual identification. Biological Journal of the Linnean Society, 68, 41-55.

Valsecchi E \& Amos W (1996) Microsatellite markers for the study of cetacean populations. Molecular Ecology, 5, 151-156.

Whitehead H (1998) Cultural selection and genetic diversity in matrilineal whales. Science, 282, 1708-1711.

Whitehead H, Waters S \& Lyrholm T (1991) Social organization of female sperm whales and their offspring: constant companions and casual acquaintances. Behavioural Ecology and Sociobiology, 29, 385-389. 